\title{
Recommendations of the Polish Association of Anaesthesia and Intensive Care Nurses on pain monitoring in Intensive Care Units using a Polish version of the Behavioural Pain Scale (BPS)
}

\author{
Zalecenia Polskiego Towarzystwa Pielęgniarek Anestezjologicznych i Intensywnej Opieki \\ w sprawie monitorowania bólu w Oddziałach Intensywnej Terapii z wykorzystaniem \\ polskiej wersji Behawioralnej skali oceny bólu (BPS)
}

\section{Aleksandra Gutysz-Wojnicka ${ }^{1,2} \odot$, Ilona Rozalska ${ }^{1,3} \oplus^{\oplus}$, Aleksandra Pawlak $^{1,3} \oplus^{\oplus}$, Katarzyna Czyż-Szypenbejl1,4 ${ }^{\circ}$, Wiesława Grabska ${ }^{1,5}$, Małgorzata Knap ${ }^{1,6} \oplus^{\circ}$, Dorota Ozga ${ }^{1,7}$ (1)}

'Polish Association of Anaesthesia and Intensive Care Nurses, Poznań/ Polskie Towarzystwo Pielęgniarek Anestezjologicznych i Intensywnej Opieki, Poznań ${ }^{2}$ Department of Nursing, School of Health Sciences, Collegium Medicum, University of Warmia and Mazury in Olsztyn/ Katedra Pielęgniarstwa, Szkoła Zdrowia Publicznego, Collegium Medicum, Uniwersytet Warmińsko-Mazurski w Olsztynie ${ }^{3}$ Department of Anaesthesiology and Intensive Care Nursing, Medical University of Lublin/ Zakład Pielęgniarstwa Anestezjologicznego i Intensywnej Opieki Medycznej, Uniwersytet Medyczny w Lublinie ${ }^{4}$ Department of Anaesthesiology Nursing \& Intensive Care, Institute of Nursing and Midwifery, Faculty of Health Sciences with Institute of Maritime and Tropical Medicine, Medical University of Gdańsk/ Zakład Pielęgniarstwa Anestezjologicznego i Intensywnej Opieki, Instytut Pielęgniarstwa i Położnictwa, Wydział Nauk o Zdrowiu z Instytutem Medycyny Morskiej i Tropikalnej, Gdański Uniwersytet Medyczny ${ }^{5}$ Ward of Anaesthesiology and Intensive Care, University Teaching Hospital in Opole/ Oddział Anestezjologii i Intensywnej Terapii, Uniwersytecki Szpital Kliniczny w Opolu ${ }^{6}$ Collegium Medicum - Institute of Health Sciences, Jan Kochanowski University of Kielce/ Collegium Medicum, Instytut Nauk o Zdrowiu, Uniwersytet Jana Kochanowskiego, Kielce ${ }^{7}$ Institute of Health Studies, College of Medical Sciences, University of Rzeszów/ Instytut Nauk o Zdrowiu, Kolegium Nauk Medycznych, Uniwersytet Rzeszowski, Rzeszów

\section{CORRESPONDING AUTHOR/AUTOR DO KORESPONDENCJ: \\ Aleksandra Gutysz-Wojnicka Department of Nursing, School of Health Sciences Collegium Medicum, University of Warmia and Mazury in Olsztyn ul. Żołnierska 14c, 10-561 Olsztyn phone/fax: 895246154 e-mail: olagut@go2.pl}

Wprowadzenie. W 2018 roku ukazała się kolejna aktualizacja Wytycznych praktyki klinicznej dotyczących zapobiegania i zarządzania bólem, pobudzeniem/sedacją, delirium, unieruchomieniem i zaburzeniami snu u dorosłych pacjentów leczonych w Oddziałach Intensywnej Terapii (OIT). Cel pracy. Celem pracy jest przedstawienie aktualnych zaleceń dotyczących zarządzania bólem u pacjentów leczonych w 0IT oraz przedstawienie algorytmu oceny i monitorowania bólu u pacjentów leczonych w OIT z wykorzystaniem polskiej wersji skali BPS (Behavioural Pain Scale), które przygotowano na podstawie systematycznego przeglądu piśmiennictwa opublikowanego w latach 2013-2018.

Metodyka badań. Wyszukiwanie publikacji naukowych przeprowadzono wykorzystując elektroniczne, anglojęzyczne oraz polskojęzyczne bazy danych. W wyszukiwaniach zastosowano następujące słowa kluczowe i ich kombinacje: ból, ocena, monitorowanie, pielęgniarka, intensywna terapia, dorosły pacjent, niezdolny do komunikacji. Wstępnie za pomocą słów kluczowych zidentyfikowano 758 prac, po wykluczeniu duplikatów i wstępnym sprawdzaniu i selekcji tytułów publikacji i abstraktów, do analizy pełnych tekstów zakwalifikowano 85 prac. W wyniku analizy i syntezy materiału badawczego sformułowano zalecenia dotyczące oceny i monitorowania bólu w 0IT.

Wnioski. Dostęp do skutecznego leczenia bólu jest fundamentalnym prawem każdego człowieka. Zalecenia Polskiego Towarzystwa Pielęgniarek Anestezjologicznych i Intensywnej Opieki dotyczące monitorowania bólu w 0IT z wykorzystaniem polskiej wersji Behawioralnej skali oceny bólu (BPS) opracowane przez Grupę roboczą ds. praktyki mogą stanowić swoisty drogowskaz w opracowaniu skutecznych lokalnych strategii zarządzania bólem w 0IT. 
Introduction. In 2018, another update of the Clinical Practice Guidelines for the Prevention and Management of Pain, Agitation/ Sedation, Delirium, Immobilization and Sleep Disorders in Adult Patients Treated in Intensive Care Units (ICUs) was released.

Aim. The study is aimed at presenting current recommendations concerning pain management in patients treated in ICU, and presenting the algorithm of pain assessment and monitoring in patients treated in ICU, using a Polish version of the BPS (Behavioural Pain Scale). The guidelines were prepared based on a systematic review of the literature published in the years 2013-2018.

Material and methods. The search for scientific publications was carried out using electronic databases in English and Polish. The following keywords and their combinations were used in the searches: pain, assessment, monitoring, nurse, intensive care, adult patient, unable to communicate. Initially, 758 papers were identified with the use of keywords. After excluding duplicates and preliminary checking and selecting the titles of publications and abstracts, 85 papers were qualified for the analysis of full text. Conclusions. Access to effective pain treatment is a fundamental human right. Recommendations of the Polish Association of Anaesthesia and Intensive Care Nurses, concerning pain monitoring in ICU using a Polish version of the Behavioural Pain Scale (BPS), developed by the Task Force for Practice, are intended to provide a specific guideline for developing effective local pain management strategies in ICU.

Key words: pain assessment, guidelines, intensive care unit

\section{INTRODUCTION}

In 2018, another update of the Clinical Practice Guidelines for the Prevention and Management of Pain, Agitation/Sedation, Delirium, Immobilization and Sleep Disorders in Adult Patients Treated in Intensive Care Units (ICU), developed by the American College of Critical Care Medicine [1], was released. In Poland, the first papers concerning the development of criteria for the assessment and monitoring of pain in sedated patients mechanically ventilated and treated in ICU were drawn up as early as in 2014 [2], and in 2016 the first results were received for the cultural adaptation and psychometric assessment of the Polish version of the BPS (Behavioural Pain Scale) [3], which is one of the tools recommended for pain assessment in this group of patients. Despite the passage of time, numerous scientific publications concerning this area of knowledge, and the measures taken aimed at training and disseminating scientific evidence regarding pain assessment and monitoring in patients unable to self-assess pain at conferences, workshops and seminars, there are still research reports demonstrating that patients treated in an ICU suffer [1]. The first step in the effective management of pain is its adequate assessment and monitoring. Medical personnel must be equipped with reliable and accurate tools for the assessment of pain in patients, both able to self-report pain and those unable to carry out its subjective assessment. In Poland, validation was conducted of two Polish versions of foreign language tools for the assessment of pain in patients that are not able to self-assess it, i.e. the Behavioural Pain Scale (BPS) [3, 4] and the Critical Care Pain Observation Tool (CPOT) $[5,6]$. The Polish version of the BPS demonstrated the necessary level of reliability and internal consistency: the Cronbach's alpha coefficient value for the Polish version of the BPS scale is 0.6883 , which allowed it to be included in the guidelines developed by the Task Force for Practice of the Polish Association of Anaesthesia and Intensive Care Nurses [3, 4]. The cultural adaptation and validation of behavioural pain assessment scales (BPS and COPT) have been conducted in many other countries and specific patient groups [7-14]. The literature, however, points out numerous barriers in the effective treatment of pain in patients in an ICU [15-18]. A consequence of this fact are, in many cases, ineffective pain management procedures in intensive care units for adults [19-24].
The paper is aimed at disseminating the current knowledge and scientific evidence necessary for the implementation of an effective pain treatment programme in intensive care units in Poland.

\section{AIM}

The study is aimed at presenting current recommendations concerning pain management in patients treated in an ICU, and presenting the algorithm of pain assessment and monitoring in patients treated in an ICU, using the Polish version of the BPS.

\section{MATERIAL AND METHODS}

The guideline for the assessment and monitoring of pain in adult patients treated in an ICU was developed by the Task Force for Practice of the Polish Association of Anaesthesia and Intensive Care Nurses (PTPAiIO). The guideline development was based on a qualitative analysis of scientific publications concerning the management of pain in adult patients treated in an ICU, identified during a systematic review of the literature for the years 2013-2018. The systematic review of the literature was prepared in accordance with the PRISMA declaration which assures reliable reporting of research results. The search of scientific publications was conducted using electronic English databases such as PubMed, Science Direct and Clinical Key, and the Polish database Polska Bibliografia Lekarska. Moreover, the manual search of electronic versions of Polish scientific journals not indexed in the international databases, e.g. Ból, Anestezjologia i Resuscytacja, Problemy Pielegniarstwa, Pielegniarstwo XXI Wieku, and Pielegniarstwo Anestezjologiczne i Intensywnej Opieki, was conducted. The following keywords and their combinations were used in the search: pain, assessment, monitoring, nurse, intensive care, adult patient and unable to communicate. Initially, 758 papers were identified with the use of keywords. After excluding duplicates and preliminary checking and selection of the titles of publications and abstracts, 85 papers were qualified for the analysis of the full text. At this selection stage, 665 papers were excluded from further analysis for the following 
reasons: studies involved groups of patients treated outside the ICU (palliative patients, children, anaesthetised, geriatric, and surgical patients); studies demonstrated the consequences of pain. The following criteria for including the eligible papers in the qualitative analysis were adopted: full text of the paper available; paper published in a scientific journal; an original paper; a paper supported with research examples/literature review; Polish or English language. Access was gained to the full texts of 50 publications which meet the qualitative analysis inclusion criteria. The number of 50 papers were subjected to qualitative analysis (Tab. 1).

\section{Tab. 1. The PRISMA Diagram}

\begin{tabular}{|c|c|}
\hline Identification & $\begin{array}{l}\text { The search of scientific publications was conducted using } \\
\text { electronic, English-language databases such as PubMed, } \\
\text { Science Direct, and Clinical Key, and a Polish-language database } \\
\text { Polska Bibliografia Lekarska; moreover, a manual search of } \\
\text { electronic versions of Polish-language scientific journals not } \\
\text { indexed in international databases, e.g. Ból, Anestezjologia i } \\
\text { Resuscytacja, Problemy Pielegniarstwa, Pielegniarstwo XXI Wieku, } \\
\text { and Pielęgniarstwo Anestezjologiczne i Intensywnej Opieki, was } \\
\text { conducted. The following keywords and their combinations } \\
\text { were used in the searches: pain, assessment, monitoring, nurse, } \\
\text { intensive care, adult patient, unable to communicate. Initially, } 758 \\
\text { papers were identified using the keywords. }\end{array}$ \\
\hline Selection & $\begin{array}{l}\text { After excluding duplicates and the preliminary checking } \\
\text { and selection of the titles of publications and abstracts, } 85 \text { papers } \\
\text { were qualified for the analysis of full text. As many as } 665 \text { papers } \\
\text { were excluded from further analysis for the following reasons: } \\
\text { studies involved groups of patients treated outside an ICU } \\
\text { (palliative patients, children, anaesthetised, geriatric, and surgical } \\
\text { patients); papers demonstrated the consequences of pain; papers } \\
\text { were concise monographs or were written in a language other } \\
\text { than Polish or English. }\end{array}$ \\
\hline Eligibility & $\begin{array}{l}\text { Criteria for including the eligible papers in the qualitative analysis: } \\
\text { full text of the paper available; paper published in a scientific } \\
\text { journal; an original paper; a paper supported with research } \\
\text { examples/literature review; Polish or English language }\end{array}$ \\
\hline Accounted for & 50 papers were subjected to \\
\hline
\end{tabular}

\section{RESULTS}

The qualitative analysis identified three thematic areas addressed in the publications under study:

1. The tools and scales for measuring pain in patients treated in ICU, and their validation in various cultural areas and patient groups, particularly including the validation of the BPS and CPOT scales [1-14]. This thematic area also included reports on new pain assessment scales for patients in ICU being developed [25-26], the effects of the synergistic use of two different pain assessment scales in patients in ICU [27-30], and the use of other, alternative pain assessment methods (BIS - bispectral index, ANI -analgesia/nociception index, galvanic skin response, pupillary response, physiological responses) [31-37].

2. Personnel training in pain management procedures in an ICU. These papers present the effects of the application of various teaching methods (audio-video) in the training of medical personnel, and the effect of the implementation of procedures and training sessions on the personnel's attitudes toward the assessment of pain in patients in an ICU [38].
3. The assessment and monitoring of pain in patients in ICU. Thematic issues related to this area include: analysis and assessment of the extent to which pain management guidelines are used in individual countries and intensive care units [19-23], challenges, difficulties and conflicts encountered by nurses using pain assessment scales in ICU [15-18], the development and implementation of pain management procedures in intensive care units and their effect on patient treatment outcomes [39-50].

The qualitative analysis and synthesis of the information obtained resulted in the recommendations concerning the assessment and monitoring of pain in patients treated in intensive care units.

Guidelines for pain assessment and monitoring in adult patients treated in the ICU

1. The management of pain in patients treated in intensive care units is an issue that requires the cooperation of all members of the therapeutic team dealing with the patient and their family.

2. Effective pain management requires the implementation of educational and organisational measures at the ward and hospital level, aimed at dispelling the myths and eliminating the barriers that hinder the effective prevention and treatment of pain in patients in ICU, and introducing the personnel to the correct use of behavioural pain assessment scales. These barriers were identified as potentially related to [15-18]:

1) Considering pain as a forgotten priority - no routine assessment of pain in the ward, inadequate cooperation in the therapeutic team.

2) Organisational barriers - understaffing or "new" personnel; no "space" in the documentation for entering pain assessment score; no information or "conversation" about pain during the ward rounds; no behavioural scales present by the patient's bed.

3) Attitudinal barriers - erroneous assumption that "sedation is sufficient" and "an unconscious patient feels no pain"; no "faith" in behavioural pain assessment scales.

4) The lack of knowledge - unfamiliarity with behavioural pain assessment scales, no practical training in using them, and either the lack of knowledge on the significance of pain or little meaning attributed to it.

3. Effective pain management in patients in ICU requires that prerequisites be met in terms of the awareness and sensitivity of ICU personnel, theoretical and practical training be conducted, and the myths associated with pain in patients with disturbed consciousness be dispelled. It is essential that the ICU personnel is confident that:

1) a significant proportion of patients in an ICU suffers,

2) pain has adverse physical and psychological effects,

3) pain adversely affects treatment outcomes,

4) sedation is not the same as analgesia.

Theoretical and practical training sessions for medical personnel should be conducted using various teaching methods $[4,38]$. 
4. Pain in patients in the ICU should be assessed, monitored, and effectively treated with the same commitment as for the other vital signs. Patients in ICU routinely experience pain at rest, during routine nursing care activities (repositioning, tracheal suctioning) and invasive procedures. Pain intensity ranges from moderate to intense. The most painful events include: arterial cannulation, drainage removal from the pleural cavity, removal of wound drainage, turning patients from side to side, body repositioning and tracheal suctioning [1].

5. The planning of measures aimed at the effective pain relief needs to include psychological and demographic factors affecting the experience of pain. The perception of pain intensity is affected by psychological (anxiety, depression) and demographic factors (young age, comorbidities, history of surgeries) [1].

6. Where the patient is able to logically communicate, verbally or non-verbally, self-assessment of pain using the NRS 0-10 scale (visual form, horizontal orientation) should be a standard procedure. Where the NRS scale cannot be used, it is appropriate to obtain at least a minimum of Yes/No information, for example: Does anything hurt? Does it hurt a lot (intensity)? Does your head hurt... (location)? Remember to give the patient the time to respond.

7. In patients unable to communicate but with preserved motor responses, the Behavioural Pain Scales for the intubated (BPS) $[1,3,4]$ and for the non-intubated (BPS-NI) as well as the Critical-Care Pain Observation Tool (CPOT) [1, 5, 6] demonstrate the best accuracy and reliability indices in pain monitoring. These can be applied in patients unable to communicate reliably but with preserved motor responses. They are not suitable for patients with the Richmond Agitation-Sedation Scale (RASS) score $\leq-4$. The BPS or CPOT scale is recommended for adult patients treated in ICU for internal medical and surgical (postoperative) reasons, excluding patients who have undergone craniocerebral trauma (atypical motor responses) and patients with burns. Behavioural scales do not specify pain intensity, and only indicate whether or not pain occurs (pain episode). The criterion for diagnosing a pain episode is the achievement of the so-called cut-off point, a BPS score of 5 or higher is considered to reflect unacceptable pain and CPOT score of 3 or higher is indicative of significant pain [1].

8. When it is recommended, and when the patient is unable to self-assess pain, the patient's family can be included in the process of pain assessment in a relative [1].

9. Vital signs (pulse, arterial blood pressure, respiratory rate, oxygen saturation, capnometry) are not reliable pain indicators in critically ill adult patients, and should only be used as a signal to start further pain assessment using appropriate and relevant methods such as (not intubated) pain self-assessment or behavioural scales (BPS, BPS-NI, CPOT). Changes in vital sign values are not specific for pain stimuli and are indicative of a stress response which may or may not be due to pain. Fluctuations in vital sign values should be regarded as a potential pain response/effect rather than an indicator of pain $[1,50]$.

10. Non-pharmacological methods of pain control (massage, music therapy, cold compresses, relaxation techniques and breathing exercises) can be offered to patients treated in an ICU along with the pharmacological procedure [1].

11. Pain management in adult patients treated in ICU should be based on routine pain assessment. Pain should be relieved prior to taking a decision to include sedative drugs according to the principle: first pain, then the need for sedation [1].

Tab. 2. Behavioural Pain Scale - the Polish version of the BPS [3]

\begin{tabular}{|c|c|c|c|c|c|}
\hline $\begin{array}{c}\text { Points } \\
\text { Category }\end{array}$ & 1 & 2 & 3 & 4 & Score \\
\hline Facial expression & $\begin{array}{l}\text { Relaxed, natural, } \\
\text { calm face expression }\end{array}$ & $\begin{array}{l}\text { Brow lowering } \\
\text { Eyelid tension/squinting } \\
\text { (orbicularis oculi muscles) }\end{array}$ & $\begin{array}{l}\text { Additionally: } \\
\text { Eyelids tightly closed } \\
\text { Nose wrinkling } \\
\text { Upper lip raising } \\
\text { Biting on the tube }\end{array}$ & $\begin{array}{c}\text { All symptoms considerably } \\
\text { intensified } \\
\text { Whole-face grimacing }\end{array}$ & \\
\hline Upper limbs & $\begin{array}{c}\text { No movement, natural } \\
\text { movement }\end{array}$ & $\begin{array}{c}\text { Partially bent calm movement } \\
\text { towards the pain stimulus, } \\
\text { touching a sore spot }\end{array}$ & $\begin{array}{l}\text { Fully bent with finger } \\
\text { flexion/fists }\end{array}$ & $\begin{array}{l}\text { firmly clenched, increased } \\
\text { tension in the upper limbs, } \\
\text { "defending" themselves } \\
\text { strongly, trying to remove } \\
\text { the tube or vascular lines }\end{array}$ & \\
\hline $\begin{array}{l}\text { Synchronisation with the } \\
\text { ventilator (tolerance of } \\
\text { mechanical ventilation) }\end{array}$ & $\begin{array}{l}\text { Tolerating ventilation } \\
\text { Breathing smoothly } \\
\text { Patient is calm } \\
\text { Capnographic record } \\
\text { "normal for the patient" }\end{array}$ & \begin{tabular}{|c|} 
Coughing sporadically, \\
tolerating ventilation most \\
of the time, Capnographic \\
record returns to "normal for \\
the patient" immediately after \\
coughing
\end{tabular} & $\begin{array}{l}\text { Fighting the ventilator } \\
\text { Coughing often, } \\
\text { Capnographic record } \\
\text { abnormal most of the time }\end{array}$ & $\begin{array}{l}\text { Unable to control breathing } \\
\text { Doctor's intervention required } \\
\text { (change of ventilator's settings) }\end{array}$ & \\
\hline
\end{tabular}

Correct citation when the Polish version of the BPS scale is used:

Gutysz-Wojnicka A, Ozga D, Onichimowski D, Mayzner-Zawadzka E. Ocena bólu za pomocą polskiej wersji Behawioralnej Skali Oceny Bólu (BPS) u pacjentów w sedacji, wentylowanych mechanicznie (Pain Assessment Using a Polish Version of the Behavioural Pain Scale (BPS) in Sedated and Mechanically Ventilated Patients) Ból, 2016;17 (3): 27-35.

Gutysz-Wojnicka A, Dorota Ozga, Ewa Mayzner-Zawadzka, Danuta Dyk, Mariusz Majewski, Anna Doboszyńska, Psychometric Assessment of Physiologic and Behavioral Pain Indicators in Polish Versions of the Pain Assessment Scales. Pain Manag Nurs. 2019; 20: 292-301. 


\section{Algorithm of pain assessment and monitoring in the ICU using the Polish version of the Behavioural Pain Scale (BPS)}

1. Plan a routine assessment of pain at rest at least four times a day, before, after and during the performance of painful procedures and after the modification of an analgesic drug dose.

2. Assess whether psychological (e.g. anxiety, depressed mood) or demographic factors (young age, a surgery, comorbidities) which exacerbate the pain experience are found in the patient.

3. Assess the patient's ability to self-assess pain through establishing verbal or non-verbal communication. In a patient able to make a logical, verbal or non-verbal contact, apply a modified visual NRS (0-10) scale.

4. In the event of difficulties in obtaining pain self-assessment in the NRS scale, obtain YES/NO answers.

5. Where there is no logical contact, assess if a behavioural scale, e.g. BPS can be used. A BPS scale can be applied where motor responses are preserved, there is no history of craniocerebral trauma and the sedation level on the RASS scale is higher $>-4$, while the contraindications for the application of a behavioural scale include: a paralysis/paresis, muscle tension disorders and the use of striated muscle relaxants.

6. Where there is no logical contact with the patient in the absence of contraindications, apply the Polish version of the BPS scale in accordance with the instructions for use:

- Observe the patient at rest for 1-2 minutes. Mark the "worst" response in each of the categories to be assessed (Tab. 2).

- During the assessment of pain, when performing diagnostic-therapeutic-nursing procedures, observe the patient's responses during the procedure, record the "worst" observed response in each of the three domains, and assign points in accordance with the description of indicators in the scale.

- Calculate and document the total pain assessment score in the behavioural scale by adding up the scores in individual domains/categories (Annex 1, Tab. 2). Assess if a pain episode has occurred (exceeded BPS cut-off point 5 points).

7. Where no behavioural pain assessment scale can be applied, identify the patient's behaviours that, in the opinion of other team members or relatives, may indicate the occurrence of a pain episode.

8. Document the pain assessment process in the patient's documentation.

9. If a pain episode has occurred, consult a doctor and apply non-pharmacological and/or pharmacological measures in accordance with the doctor's recommendations.

\section{CONCLUSIONS}

Access to effective pain treatment is a fundamental human right. Unfortunately, in intensive care units, particularly for patients unable to communicate successfully, the effective prevention and treatment of pain remain an unresolved problem. The treatment of patients in an intensive care unit is interdisciplinary in nature, and so should be the treatment of pain. There are many barriers to the effective implementation of pain management procedures in the ICU. The elimination of these barriers requires intensive theoretical and practical training sessions for medical personnel, a change in attitudes and organisational support. The recommendations of the Polish Association of Anaesthesia and Intensive Care Nurses, concerning pain monito-ring in intensive care units using the Polish version of the Behavioural Pain Scale (BPS), developed by the Task Force for Practice, are intended to provide a specific guidelines for developing effective local pain management strategies in an ICU. 


\section{Zalecenia Polskiego Towarzystwa Pielęgniarek Anestezjologicznych i Intensywnej Opieki w sprawie monitorowania bólu w Oddziałach Intensywnej Terapii z wykorzystaniem polskiej wersji Behawioralnej skali oceny bólu (BPS)}

\section{WPROWADZENIE}

W 2018 roku ukazała się kolejna aktualizacja Wytycznych praktyki klinicznej dotyczących zapobiegania i zarządzania bólem, pobudzeniem/sedacją, delirium, unieruchomieniem i zaburzeniami snu u dorosłych pacjentów leczonych w Oddziałach Intensywnej Terapii (OIT) opracowanych przez the American College of Critical Care Medicine [1]. W Polsce pierwsze prace dotyczace opracowania kryteriów oceny i monitorowania bólu u pacjentów w sedacji, wentylowanych mechanicznie, leczonych w OIT rozpoczęto już w roku 2014 [2], a w roku 2016 opublikowano pierwsze wyniki adaptacji kulturowej i oceny psychometrycznej polskiej wersji skali BPS [3], która jest jednym $\mathrm{z}$ narzędzi zalecanych do oceny bólu w tej grupie pacjentów. Pomimo upływu czasu, licznych publikacji naukowych dotyczących tego obszaru wiedzy, podejmowania działań szkoleniowych i popularyzujących dowody naukowe z zakresu oceny i monitorowania bólu u pacjentów niezdolnych do jego samooceny w czasie konferencji, warsztatów i seminariów, wciąż napotykamy na raporty $z$ badań wskazujące, że pacjenci leczeni w OIT cierpią [1]. Pierwszym krokiem w skutecznym zarządzaniu bólem jest jego adekwatna ocena i monitorowanie. Personel medyczny musi być wyposażony w rzetelne i trafne narzędzia do oceny bólu zarówno u pacjentów zdolnych do samoraportowania bólu, jak i tych niezdolnych do subiektywnej oceny bólu. W Polsce przeprowadzono walidację dwóch polskich wersji obcojęzycznych narzędzi do oceny bólu u pacjentów, niezdolnych do jego samooceny - Behavioral Pain Scale (BPS) [3, 4], oraz Critical Care Pain Observation Tool (CPOT) [5, 6]. Polska wersja skali BPS wykazała się niezbędnym poziomem rzetelności i spójności wewnętrznej, wartość współczynnika Cronbach’s alpha dla polskiej wersji skali BPS wynosi 0.6883 , co pozwoliło na uwzględnienie jej w wytycznych opracowanych przez Grupę roboczą ds. praktyki Polskiego Towarzystwa Pielęgniarek Anestezjologicznych i Intensywnej Opieki $[3,4]$. Adaptacją kulturowa i walidacja behawioralnych skal oceny bólu (BPS i COPT) została przeprowadzona w wielu innych krajach oraz specyficznych grupach pacjentów [7-14]. W piśmiennictwie wskazuje się jednakże na liczne bariery w skutecznym leczeniu bólu u pacjentów w OIT [15-18]. Konsekwencją tego faktu jest w wielu przypadkach nieskuteczne postepowanie przeciwbólowe w oddziałach intensywnej terapii dla dorosłych [19-24].
Praca ta ma służyć popularyzacji aktualnej wiedzy i dowodów naukowych niezbędnych do wdrożenia skutecznego programu leczenia bólu w oddziałach intensywnej terapii w Polsce.

\section{CEL PRACY}

Celem pracy jest przedstawienie aktualnych zaleceń dotyczących zarządzania bólem u pacjentów leczonych w OIT oraz przedstawienie algorytmu oceny i monitorowania bólu u pacjentów leczonych w OIT z wykorzystaniem polskiej wersji skali BPS.

\section{MATERIA I METODYKA}

Wytyczne oceny i monitorowania bólu u pacjentów dorosłych leczonych w OIT zostały opracowane przez Grupę roboczą ds. praktyki działającą przy Polskim Towarzystwie Pielęgniarek Anestezjologicznych i Intensywnej Opieki (PTPAiIO). Podstawą opracowania wytycznych była analiza jakościowa publikacji naukowych dotyczących zarządzania bólem u pacjentów dorosłych leczonych w OIT zidentyfikowanych w toku systematycznego przeglądu piśmiennictwa za lata 2013-2018. Systematyczny przegląd piśmiennictwa przygotowano zgodnie $\mathrm{z}$ deklaracją PRISMA, która zapewnia rzetelne raportowanie wyników badania. Wyszukiwanie publikacji naukowych przeprowadzono wykorzystując elektroniczne, anglojęzyczne bazy danych takie jak PubMed, Science Direct, Clinical Key oraz polskojęzyczną bazę Polska Bibliografia Lekarska, przeprowadzono także ręczne przeszukiwanie elektronicznych wersji polskojęzycznych czasopism naukowych nie indeksowanych w bazach międzynarodowych, takie jak: Ból, Anestezjologia i Resuscytacja, Problemy Pielegniarstwa, Pielegniarstwo XXI wieku, Pielęgniarstwo Anestezjologiczne i Intensywnej opieki. W wyszukiwaniach zastosowano następujące słowa kluczowe i ich kombinacje: ból, ocena, monitorowanie, pielęgniarka, intensywna terapia, dorosły pacjent, niezdolny do komunikacji. Wstępnie za pomocą słów kluczowych zidentyfikowano 758 prac, po wykluczeniu duplikatów i wstępnym sprawdzaniu i selekcji tytułów publikacji i abstraktów, do analizy pełnych tekstów zakwalifikowano 85 prac. Na tym etapie selekcji 665 prac zostało wykluczonych z dalszej analizy z następujących powodów: badania obejmowały grupy pacjentów leczonych poza OIT (pacjenci paliatywni, dzieci, po znieczuleniu, geriatryczni, chirurgiczni), 
badania ukazywały konsekwencje bólu, stanowiły opracowania zwarte lub napisane były w języku innym niż polski lub angielski. Przyjęto następujące kryteria włączenia zakwalifikowanych prac do analizy jakościowej: dostępny pełny tekst pracy, praca opublikowana w czasopiśmie naukowym, praca oryginalna, praca poglądowa/przegląd piśmiennictwa, język polski lub angielski. Uzyskano dostęp do pełnych tekstów 50 publikacji, z czego jedna nie spełniała kryteriów włączenia do analizy jakościowej. Analizie jakościowej poddano 50 prac (Tab. 1).

Tab. 1. Diagram PRISMA

\begin{tabular}{|c|c|}
\hline Identyfikaja & $\begin{array}{l}\text { Wyszukiwanie publikacji naukowych przeprowadzono } \\
\text { wykorzystujajc elektroniczne, anglojęzyczne bazy } \\
\text { danych takie jak PubMed, Science Direct, Clinical } \\
\text { Key oraz polskojęzyczną bazę Polska Bibliografia } \\
\text { Lekarska, przeprowadzono także ręzne przeszukiwanie } \\
\text { elektronicznych wersji polskojęzycznych czasopism } \\
\text { naukowych nie indeksowanych w bazach } \\
\text { międzynarodowych, takie jak: Ból, Anestezjologia } \\
\text { i Resuscytacja, Problemy Pielegniarstwa, Pielegniarstwo } \\
\text { XXI wieku, Pielęgniarstwo Anestezjologiczne i Intensywnej } \\
\text { opieki. W wyszukiwaniach zastosowano następujące słowa } \\
\text { kluczowe i ich kombinacje: ból, ocena, monitorowanie, } \\
\text { pielęgniarka, intensywna terapia, dorosty pacjent, niezdolny } \\
\text { do komunikacji. Wstępnie za pomoca stów kluczowych } \\
\text { zidentyfikowano } 758 \text { prac. } \\
\end{array}$ \\
\hline Selekcja & $\begin{array}{l}\text { Po wykluczeniu duplikatów i wstępnym sprawdzaniu i } \\
\text { selekcji tytułów publikacji i abstraktów, do analizy pełnych } \\
\text { tekstów zakwalifikowano } 85 \text { prac. } 665 \text { prac zostało } \\
\text { wykluczonych z dalszej analizy z następujących powodów: } \\
\text { badania obejmowały grupy pacjentów leczonych poza 0IT } \\
\text { (pacjenci paliatywni, dzieci, po znieczuleniu, geriatryczni, } \\
\text { chirurgiczni), badania ukazywały konsekwencje bólu, } \\
\text { stanowiły opracowania zwarte lub napisane były w języku } \\
\text { innym niż polski lub angielski. }\end{array}$ \\
\hline Kwalifikowalność & $\begin{array}{c}\text { Kryteria włączenia zakwalifikowanych prac do analizy } \\
\text { jakościowej: dostępny pełny tekst pracy, praca opublikowana } \\
\text { w czasopiśmie naukowym, praca oryginalna, praca } \\
\text { poglądowa/przegląd piśmiennictwa, język polski lub } \\
\text { angielski. }\end{array}$ \\
\hline Uwzględnione & 50 prac poddano analizie jakośc \\
\hline
\end{tabular}

\section{WYNIKI}

W toku analizy jakościowej zidentyfikowano trzy obszary tematyczne poruszane $\mathrm{w}$ badanych publikacjach: 1. Narzędzia i skale do pomiaru bólu u pacjentów leczonych w OIT i ich walidacja w różnych obszarach kulturowych i różnych grupach pacjentów, w tym szczególnie walidacja skal BPS i CPOT [1-14]. Ten obszar tematyczny zawierał również doniesienia o opracowaniu nowych skalach do oceny bólu u pacjentów w OIT [25-26] efektach synergicznego użycia dwóch różnych skal oceny bólu u pacjentów OIT [27-30], wykorzystanie innych alternatywnych metod oceny bólu (Indeks bispektralny BIS, wskaźnik nocycepcja/analgesa A.N.I., przewodnictwo skórne, reakcja źrenic, reakcje fizjologiczne) [31-37].
2. Szkolenia personelu z zakresu procedur zarządzania bólem w OIT. W pracach przedstawiono efekty wykorzystanie różnych metod dydaktycznych (audio-video) w szkoleniu personelu medycznego oraz wpływ wdrażania procedur i szkoleń na postawy personelu wobec oceny bólu u pacjentów w OIT [38].

3. Ocena i monitorowanie bólu u pacjentów w OIT. Zagadnienia tematyczne związane $\mathrm{z}$ tym obszarem to: analiza i ocena stopnia wykorzystywania wytycznych zarządzania bólem w poszczególnych krajach i oddzialach intensywnej terapii [19-23], wyzwania, trudności i konflikty stojące przed pielęgniarkami stosującymi skale oceny bólu w OIT [15-18], opracowywanie i wdrażanie procedur zarządzania bólem w oddziałach intensywnej terapii i ich wpływ na wyniki leczenia pacjentów [39-50].

Analiza jakościowa i synteza uzyskanych informacji pozwoliła na sformułowanie zaleceń dotyczących oceny $i$ monitorowania bólu u pacjentów leczonych w oddziałach intensywnej terapii.

Wytyczne oceny i monitorowania bólu u pacjentów

\section{dorosłych leczonych w OIT}

1. Zarządzanie bólem u pacjentów leczonych w oddziałach intensywnej terapii jest zagadnieniem wymagającym współpracy wszystkich członków zespołu terapeutycznego zajmującego się pacjentem i jego rodziną.

2. Skuteczne zarządzanie bólem wymaga wdrożenia działań edukacyjnych i organizacyjnych na szczeblu oddziału i szpitala, których celem jest obalenie mitów i barier utrudniających skuteczne zapobieganie i leczenie bólu u pacjentów w OIT oraz zapoznanie personelu z prawidłowym stosowaniem behawioralnych skal oceny bólu. Bariery te zostały zidentyfikowane jako potencjalnie związane z [15-18]:

1) Traktowaniem bólu jak zapomnianego priorytetu brak rutynowej oceny bólu w oddziale, niewłaściwa współpraca w zespole terapeutycznym.

2) Barierami organizacyjnymi - zbyt mało personelu lub "nowy” personel, brak „miejsca” w dokumentacji na zapisanie wyniku oceny bólu, brak informacji i „rozmowy” w czasie obchodu o bólu, brak skal behawioralnych dostępnych przy łóżku pacjenta

3) Barierami w postawach - błędne założenie, że „wystarczy sedacja”, a "pacjent nieprzytomny nie odczuwa bólu”, brak ,wiary” w behawioralne skale oceny bólu

4) Brakiem wiedzy - nieznajomość behawioralnych skal oceny bólu, brak szkolenia praktycznego w ich wykorzystaniu, brak wiedzy o znaczeniu bólu lub przypisywane mu małego znaczenie.

3. Skuteczne zarządzanie bólem u pacjentów w OIT wymaga spełnienia warunków wstępnych w zakresie świadomości i wrażliwości personelu oddziału intensywnej terapii, przeprowadzenia szkoleń teoretycznych i praktycznych oraz obalania mitów związanych $\mathrm{z}$ bólem $\mathrm{u}$ chorych $\mathrm{z}$ zaburzeniami świadomości. Istotnym jest aby personel oddziału był przekonany, że: 
1) znaczna część pacjentów w OIT cierpi,

2) ból ma niekorzystne skutki fizyczne i psychologiczne,

3) ból wpływa negatywnie na wyniki leczenia,

4) sedacja nie jest tym samym co analgezja.

Szkolenia teoretyczne i praktyczne personelu medycznego powinny być przeprowadzane $\mathrm{z}$ wykorzystaniem różnych metod dydaktycznych $[4,38]$.

4. Ból u pacjentów w OIT powinien być oceniany, monitorowany i skutecznie leczony $z$ takim samym zaangażowaniem jak w przypadku pozostałych parametrów życiowych. Chorzy w OIT rutynowo doświadczają bólu w spoczynku, podczas rutynowych czynności pielęgnacyjnych (zmiana ułożenia, odsysanie z tchawicy) i inwazyjnych procedur. Nasilenie bólu waha się w granicach od umiarkowanego do silnego. Najbardziej bolesne są: kaniulację naczyń tętniczych, usuwanie drenu z jamy opłucnej, usuwanie drenażu ran, obracanie na boki, zmiany ułożenia ciała oraz odsysanie wydzieliny z tchawicy [1].

5. W planowaniu działań zmierzających do skutecznego uśmierzenia bólu należy uwzględnić czynniki psychologiczne i demograficzne wpływające na odczuwanie bólu. Na odczuwanie nasilenia bólu mają wpływ czynniki psychologiczne (lęk, depresja) i demograficzne (młody wiek, choroby współistniejące, przebyte zabiegi operacyjne) [1].

6. Samoocena bólu za pomocą skali NRS 0-10 (forma wizualna, orientacja pozioma), w przypadku pacjenta zdolnego do logicznej komunikacji werbalnej lub pozawerbalnej powinna być standardowym sposobem postepowania. Jeżeli nie można wykorzystać skali NRS należy uzyskać choćby minimum informacji typu Tak/Nie np. Czy coś boli?, Czy bardzo boli (nasilenie)? Czy boli głowa ... (lokalizacja)? Należy pamiętać, aby dać pacjentowi czas na odpowiedź.

7. U pacjentów niezdolnych do komunikacji, ale z zachowanymi reakcjami ruchowymi skale Behavioral Pain Scale dla zaintubowanych (BPS) $[1,3,4]$ i niezaintubowanych (BPS-NI) oraz the Critical-Care Pain Observation Tool (CPOT) $[1,5,6]$ wykazują najlepsze wskaźniki trafności i rzetelności w monitorowaniu bólu. Można je zastosować, u pacjentów niezdolnych do rzetelnej komunikacji, ale $z$ zachowanymi reakcjami ruchowymi. Nie nadają się one dla pacjentów z Richmond Agitation-Sedation Scale $($ RASS $) \leq-4$. Skale BPS lub CPOT zalecane są u pacjentów dorosłych leczonych w OIT z przyczyn internistycznych i chirurgicznych (pooperacyjnych), z wykluczeniem pacjentów po urazach czaszkowo-mózgowych (nietypowe reakcje ruchowe) i oparzeniach. Skale behawioralne nie określają natężenia bólu. Jedynie to, czy ból występuje (epizod bólu), czy też nie. Kryterium rozpoznania epizodu bólu stanowi osiągnięcie tzw. punktu odcięcia czyli wzrost $\uparrow$ wyniku oceny o co najmniej 2 pkt. Punkt odcięcia dla skal BPS (zakres 3-12) to 5 i więcej punktów, a w skali CPOT (zakres 0-8) to 3 i więcej punktów [1].
8. Gdy jest to wskazane, oraz gdy pacjent jest niezdolny do samooceny bólu, rodzina pacjenta może być włączona w proces oceny bólu u bliskiej osoby [1].

9. Parametry życiowe (tętno, ciśnienie tętnicze krwi, liczba oddechów, poziom saturacji, kapnometria) nie są rzetelnymi wskaźnikami bólu u dorosłych pacjentów krytycznie chorych i powinny być używane jedynie jako sygnał do rozpoczęcia dalszej oceny bólu przy użyciu odpowiednich i trafnych metod takich jak samoocena bólu lub skale behawioralne (BPS, BPS-NI, CPOT). Zmiany w wartościach parametrów fizjologicznych nie są specyficzne dla bodźców bólowych, świadczą o reakcji stresowej, która może, ale nie musi wynikać z bólu. Wahania wartości parametrów życiowych powinny być traktowane jako potencjalna reakcja na ból / skutek bólu, a nie wskaźnik bólu [1, 50].

10. Pozafarmakologiczne metody zwalczania bólu (masaż, muzykoterapia, okłady zimne, techniki relaksacyjne - ćw. oddechowe) mogą być proponowane pacjentom leczonym w OIT, łącznie z postępowaniem farmakologicznym [1].

11. Zarządzanie bólem u dorosłych pacjentów leczonych w OIT powinno opierać się na rutynowej ocenie bólu. Ból powinien być uśmierzony przed podjęciem decyzji o włączeniu leków sedacyjnych wg zasady najpierw ból, następnie potrzeba sedacji [1].

Algorytm oceny i monitorowania bólu w OIT z wykorzystaniem polskiej wersji behawioralnej skali oceny bólu (BPS)

1. Zaplanuj rutynową ocenę bólu w spoczynku co najmniej 4 razy na dobę, przed, po i w trakcie wykonywania procedur bolesnych oraz po modyfikacji dawki leku przeciwbólowego.

2. Oceń czy u pacjenta występują czynniki psychologiczne (np. lęk, obniżony nastrój) lub demograficzne (młody wiek, zabieg operacyjny, choroby współistniejące), które nasilają doznania bólowe.

3. Oceń zdolność pacjenta do samooceny bólu poprzez nawiązanie komunikacji werbalnej lub niewerbalnej. U pacjenta w logicznym kontakcie werbalnym lub niewerbalnym zastosuj zmodyfikowaną wzrokową skalę NRS (0-10).

4. W przypadku trudności w uzyskaniu samooceny bólu w skali NRS, uzyskaj odpowiedzi typu TAK/NIE.

5. W przypadku braku kontaktu logicznego oceń czy można zastosować skalę behawioralną np. BPS. Aby zastosować skalę BPS muszą być zachowane reakcje ruchowe, brak urazu czaszkowo-mózgowego w wywiadzie oraz poziom sedacji w skali RASS powyżej > -4, przeciwwskazaniami do zastosowania skali behawioralnej są: porażenia/niedowłady, zaburzenia napięcia mięśniowego, stosowanie leków zwiotczających mięśnie poprzecznie prążkowane.

6. W przypadku braku kontaktu logicznego i braku przeciwwskazań zastosuj polską wersje skali BPS zgodnie z instrukcją jej wykorzystania:

- Obserwuj pacjenta w spoczynku przez 1-2 min. Zaznacz „najgorszą” reakcję w każdej z kategorii podlegającej ocenie (Tab. 2). 


\section{Zalecenia PTPAilO dotyczące monitorowania bólu w OIT}

Tab. 2. Behawioralna Skala Oceny Bólu - polska wersja skali BPS (Behavioural Pain Scale) [3]

\begin{tabular}{|c|c|c|c|c|c|}
\hline $\begin{array}{c}\text { Punkty } \\
\text { Kategoria }\end{array}$ & 1 & 2 & 3 & 4 & Wynik \\
\hline Wyraz twarzy & $\begin{array}{l}\text { Rozluźniony, naturalny, } \\
\text { spokojny wyraz twarzy }\end{array}$ & $\begin{array}{l}\text { Obniżenie brwi } \\
\text { Napięcie /mrużenie powiek } \\
\text { (mięsnie okrężne oka }\end{array}$ & $\begin{array}{c}\text { Dodatkowo: } \\
\text { Zaciskanie powiek } \\
\text { Marszczenie nosa, Uniesienie } \\
\text { górnej wargi, Zagryzanie rurki }\end{array}$ & $\begin{array}{l}\text { Intensywnie nasilone } \\
\text { wszystkie objawy } \\
\text { Grymasy całej twarzy }\end{array}$ & \\
\hline Kończyny górne & $\begin{array}{l}\text { Bez ruchu, } \\
\text { naturalny ruch }\end{array}$ & $\begin{array}{l}\text { Częściowo zgięte } \\
\text { spokojny ruch w kierunku } \\
\text { bodźca bólowego, } \\
\text { dotyka, bolące miejsce }\end{array}$ & $\begin{array}{l}\text { Zgięte w pełnym zakresie } \\
\text { wraz z zaciskaniem } \\
\text { palców/pięści }\end{array}$ & $\begin{array}{c}\text { Silnie przykurczone, } \\
\text { wzmożone napięcie w obrębie } \\
\text { kończyn górnych, } \\
\text { „Broni się" intensywnie, } \\
\text { próbuje usunąc rurkę lub linie } \\
\text { naczyniowe } \\
\end{array}$ & \\
\hline $\begin{array}{l}\text { Synchronizacja } \\
\text { z respiratorem (tolerancja } \\
\text { wentylacji mechanicznej) }\end{array}$ & $\begin{array}{l}\text { Toleruje wentylację } \\
\text { Oddech płynny } \\
\text { Pacjent spokojny } \\
\text { Zapis kapnograficzny } \\
\text { W, „normie dla pacjenta }^{\text {„I }}\end{array}$ & $\begin{array}{c}\text { Kaszle sporadycznie, Toleruje } \\
\text { wentylację w większości } \\
\text { czasu, Zapis kapnograficzny } \\
\text { wraca do „normy dla pacjenta” } \\
\text { zaraz po kaszlu }\end{array}$ & $\begin{array}{c}\text { Kłóci się z respiratorem" } \\
\text { Kaszle często, } \\
\text { Zapis kapnograficzny } \\
\text { zaburzony w większości czasu }\end{array}$ & $\begin{array}{l}\text { Niezdolny do kontrolowania } \\
\text { oddechu, } \\
\text { Wymagana interwencja } \\
\text { lekarza (zmiana nastawów } \\
\text { respiratora) }\end{array}$ & \\
\hline \multicolumn{5}{|l|}{ Całkowita liczba punktów } & ...../12 \\
\hline
\end{tabular}

Prawidłowe cytowanie w przypadku wykorzystania polskiej wersji skali BPS:

Gutysz-Wojnicka A, Ozga D, Onichimowski D, Mayzner-Zawadzka E. Ocena bólu za pomocą polskiej wersji Behawioralnej Skali Oceny Bólu (BPS) u pacjentów w sedacji, wentylowanych mechanicznie. Pain assessment using a Polish version of the Behavioral Pain Assessment Scale in sedated and mechanically ventilated patients. Ból. 2016:17 (3): 27-35.

Gutysz-Wojnicka A, Dorota Ozga, Ewa Mayzner-Zawadzka, Danuta Dyk, Mariusz Majewski, Anna Doboszyńska, Psychometric Assessment of Physiologic and Behavioral Pain Indicators in Polish Versions of the Pain Assessment Scales. Pain Manag Nurs. 2019; 20: 292-301.

- Podczas oceny bólu w czasie wykonywania procedur diagnostyczno-leczniczo-pielegnacyjnych obserwuj reakcje pacjenta w czasie trwania procedury, zanotuj „najgorszą” zaobserwowaną reakcję w każdej $\mathrm{z}$ trzech domen i przypisz punkty zgodnie $\mathrm{z}$ opisem wskaźników w skali.

- Oblicz i udokumentuj ogólny wynik oceny bólu w skali behawioralnej, w tym celu należy zsumować wyniki w poszczególnych domenach/kategoriach (załącznik 1, tab. 2). Oceń czy wystąpił epizod bólu (przekroczony punkt odcięcia BPS $5 \mathrm{i}$ więcej punktów).

7. W przypadku braku możliwości zastosowania behawioralnej skali oceny bólu ustal zachowania pacjenta, które zdaniem innych członków zespołu lub osób bliskich mogą wskazywać na wystąpienie epizodu bólu.

8. Udokumentuj proces oceny bólu w dokumentacji pacjenta.

9. Jeżeli wystąił epizod bólu skonsultuj się z lekarzem, zastosuj środki pozafarmakologiczne i / lub farmakologiczne zgodnie ze zleceniem lekarza.

\section{PODSUMOWANIE}

Dostęp do skutecznego leczenia bólu jest fundamentalnym prawem każdego człowieka. Niestety w oddziałach intensywnej terapii, szczególnie w stosunku do pacjentów niezdolnych do efektywnej komunikacji, skuteczne zapobieganie i leczenie bólu nadal pozostaje nierozwiązanym problemem. Leczenie chorych w oddziale intensywnej terapii ma charakter interdyscyplinarny i taki też charakter powinno mieć leczenie bólu. Istnieje wiele barier w skutecznym wdrażaniu procedur zarządzania bólem w OIT. Likwidacja tych barier wymaga prowadzenia intensywnych teoretycznych i praktycznych szkoleń personelu medycznego, zmiany postaw oraz wsparcia organizacyjnego. Zalecenia
Polskiego Towarzystwa Pielęgniarek Anestezjologicznych i Intensywnej Opieki w sprawie monitorowania bólu w oddziałach intensywnej terapii z wykorzystaniem polskiej wersji Behawioralnej skali oceny bólu (BPS) opracowane przez Grupę Roboczą ds. praktyki mają stanowić swoisty drogowskaz w opracowaniu skutecznych lokalnych strategii zarządzania bólem w OIT.

\section{ORCID}

Aleksandra Gutysz-Wojnicka (iD) https://orcid.org/0000-0002-3813-3824 Ilona Rozalska (iD https://orcid.org/0000-0002-8485-8623 Aleksandra Pawlak (iD https://orcid.org/0000-0001-6359-8933 Katarzyna Czyż-Szypenbejl iD https://orcid.org/0000-0001-9225-2958 Małgorzata Knap (D) https://orcid.org/0000-0003-0425-7631 Dorota 0zga iD https://orcid.org/0000-0002-9457-9388

\section{REFERENCES/PIŚMIENNICTWO}

1. Devlin JW, Skrobik Y, Gélinas C, et al. Clinical Practice Guidelines for the Prevention and Management of Pain, Agitation/Sedation, Delirium, Immobility, and Sleep Disruption in Adult Patients in the ICU. Crit Care Med. 2018; 46(9): e825-e873 doi: doi: $10.1097 /$ CCM.0000000000003299.

2. Gutysz-Wojnicka A, Dyk D, Ozga D, Cudak E. Pozawerbalne wskaźniki bólu u pacjentów nieprzytomnych, wentylowanych mechanicznie. Anestezjologia i Ratownictwo. 2014; 8(1): 23-31.

3. Gutysz-Wojnicka A, Ozga D, Onichimowski D, Mayzner-Zawadzka E. Ocena bólu za pomocą polskiej wersji Behawioralnej Skali Oceny Bólu (BPS) u pacjentów w sedacji, wentylowanych mechanicznie. Ból. 2016; 17(3): 27-35 doi: 10.5604/01.3001.0009.5271.

4. Gutysz-Wojnicka A, Ozga D, Mayzner-Zawadzka E, et al. Psychometric Assessment of Physiologic and Behavioral Pain Indicators in Polish Versions of the Pain Assessment Scales. Pain Manag Nurs. 2019; 20(3): 292-301 doi: 10.1016/j.pmn.2018.07.006.

5. Kotfis K, Strzelbicka M, Zegan-Barańska M, et al. Validation of the behavioral pain scale to assess pain intensity in adult, intubated postcardiac surgery patients: A cohort observational study - POL-BPS. Medicine (Baltimore). 2018; 97(38): e12443. doi: 10.1097/MD.0000000000012443.

6. Cudak E, Dyk D, Gutysz-Wojnicka A, et al. Behawioralna ocena bólu u pacjentów na Oddziale Intensywnej Terapii - wyniki wstępne. Pielęg Pol. 2018; 68(2): 152-157 http://dx.doi.org/10.20883/pielpol.2018.18. 


\section{Aleksandra Gutysz-Wojnicka, llona Rozalska, Aleksandra Pawlak, et al}

7. Aktas YY, Karabulut N. A Turkish Version of the Critical-Care Pain Observation Tool: Reliability and Validity Assessment. J Perianesth Nurs. 2017; 32(4): 341-351 doi. org/10.1016/j.jopan.2015.12.01541.

8. Jie C, Qian L, Xiao-Ying W, et al. Reliability and validity of the Chinese version of the behavioral pain scale in intubated and non-intubated critically ill patients: Two cross-sectional studies. Int J Nurs Stud. 2016; 61: 63-71 doi.org/10.1016/j. ijnurstu.2016.05.013.

9. Latorre-Marco I, Acevedo-Nuevo M, Solís-Muñoz M, et al. Psychometric validation of the behavioral indicators of pain scale for the assessment of pain in mechanically ventilated and unable to self-report critical care patients. Med Intensiva. 2016; 40(8): 463-473 doi: 10.1016/j.medin.2016.06.004.

10. Morete MC, Mofatto SC, Pereira CA, et al. Translation and cultural adaptation of the Brazilian Portuguese version of the Behavioral Pain Scale. Rev Bras Ter Intensiva. 2014; 26(4): 373-378 doi: 10.5935/0103-507X.20140057.

11. Klein C, Caumo W, Gélinas C, et al. Validation of Two Pain Assessment Tools Using a Standardized Nociceptive Stimulation in Critically III Adults. J Pain Symptom Manage. 2018; 56(4): 594-601 doi.org/10.1016/j.jpainsymman.2018.06.014.

12. Rafiei $M$, Ghadami A, Irajpour A, Feizi A. Validation of critical care pain observation tool in patients hospitalized in surgical wards. Iran J Nurs Midwifery Res. 2016; 21(5): 464-469 doi: 10.4103/1735-9066.193391.

13. Echegaray-Benites C, Kapoustina 0, Gélinas C. Validation of the use of the CriticalCare Pain Observation Tool (CPOT) with brain surgery patients in the neurosurgical intensive care unit. Intensive Crit Care Nurs. 2014; 30(5): 257-265 doi.org/10.1016/j. iccn.2014.04.002.

14. Li Q, Wan X, Gu C, Yu Y, et al. Pain Assessment Using the Critical-Care Pain Observation Tool in Chinese Critically III Ventilated Adults. J Pain Symptom Manage. 2014; 48 (5):975-982 https://doi.org/10.1016/j.jpainsymman.2014.01.014

15. Deldar K, Froutan R, Ebadi A. Challenges faced by nurses in using pain assessment scale in patients unable to communicate: a qualitative study. BMC Nurs. 2018; 6(17): 11 doi: 10.1186/s12912-018-0281-3. ecollection 2018.

16. Mędrzycka-Dąbrowska WA, Dąbrowski S, Basiński A, Małecka-Dubiela A. Identification and comparison of barriers to assessing and combating acute and postoperative pain in elderly patients in surgical wards of Polish hospitals: A Multicenter Study. Adv Clin Exp Med. 2016; 25(1): 135-144 doi: 10.17219/ acem/34698.

17. Sneyers B, Laterre PF, Perreault MM, et al. Current practices and barriers impairing physicians' and nurses' adherence to analgo-sedation recommendations in the intensive care unit-a national survey. Crit Care. 2014; 8: 655 doi: 10.1186/s13054-140655-1.

18. Wøien H, Bjørk IT. Intensive care pain treatment and sedation: Nurses' experiences of the conflict between clinical judgement and standardised care: An explorative study. Intensive Crit Care Nurs. 2013; 29(3): 128-136 https://doi.org/10.1016/j. iccn.2012.11.003.

19. Chawla R, Myatra SN, Ramakrishnan N, et al. Current practices of mobilization, analgesia, relaxants and sedation in Indian ICUs: A survey conducted by the Indian Society of Critical Care Medicine. Indian J Crit Care Med. 2014;18(9): 575-584 doi: 10.4103/0972-5229.140146.

20. Luetz A, Balzer F, Radtke FM, et al. Delirium, sedation and analgesia in the intensive care unit: a multinational, two-part survey among intensivists. PLoS One. 2014; 9(11): e110935 doi: 10.1371/journal.pone.0110935. eCollection 2014.

21. Morandi A, Piva S, Ely EW, et al. Kaps Worldwide Survey of the "Assessing Pain, Both Spontaneous Awakening and Breathing Trials, Choice of Drugs, Delirium Monitoring/ Management, Early Exercise/Mobility, and Family Empowerment" (ABCDEF) Bundle. Crit Care Med. 2017; 45(11): e1111-e1122 doi: 10.1097//CCM.0000000000002640.

22. Wang J, Peng ZY, Zhou WH, et al. A National Multicenter Survey on Management of Pain, Agitation, and Delirium in Intensive Care Units in China. Chin Med J (Engl). 2017; 130(10): 1182-1188 doi: 10.4103/0366-6999.205852.

23. Kemp HI, Bantel C, Gordon F, et al. Pain Assessment in INTensive care (PAINT): an observational study of physician-documented pain assessment in 45 intensive care units in the United Kingdom. Anaesthesia. 2017; 72(6): 737-748 doi: 10.1111/ anae.13786.

24. Roos-Blom MJ, Gude WT, Spijkstra JJ, et al. Measuring quality indicators to improve pain management in critically ill patients. J Crit Care. 2019; 49: 136-142 doi. org/10.1016/j.jcrc.2018.10.027.

25. Gosselin E, Bourgault P, Lavoie S, et al. Development and Validation of an Observation Tool for the Assessment of Nursing Pain Management Practices in Intensive Care Unit in a Standardized Clinical Simulation Setting. Pain Manag Nurs. 2014; 15(4): 720-730 doi.org/10.1016/j.pmn.2013.05.003.

26. Wiegand DL, Wilson T, Pannullo D, et al. Measuring Acute Pain Over Time in the Critically III Using the Multidimensional Objective Pain Assessment Tool (MOPAT). Pain Manag Nurs. 2018; 19(3): 277-287 doi: 10.1016/j.pmn.2017.10.013.
27. Suzuki T. Does the combination use of two pain assessment tools have a synergistic effect? Jntensive Care. 2017; 5: 1 doi: 10.1186/s40560-016-0195-7. eCollection 2017.

28. Severgnini P, Pelosi P, Contino E, et al. Accuracy of Critical Care Pain Observation Tool and Behavioral Pain Scale to assess pain in critically ill conscious and unconscious patients: prospective, observational study. J Intensive Care. 2016; (4): 68 doi: 10.1186/s40560-016-0192-x. eCollection 2016.

29. Rijkenberg S, Stilma W, Endeman H, et al. Pain measurement in mechanically ventilated critically ill patients: Behavioral Pain Scale versus Critical-Care Pain Observation Tool. J CritCare. 2015; 30(1): 167-172 doi.org/10.1016/j.jcrc.2014.09.007.

30. Kiavar M, Azarfarin R, Totonchi $Z$, et al. Comparison of Two Pain Assessment Tools, "Facial Expression" and "Critical Care Pain Observation Tool" in Intubated Patients After Cardiac Surgery. Anesth Pain Med. 2016; 6(1): e33434 doi: 10.5812/ aapm.33434. eCollection 2016.

31. Shan K, Cao W, Yuan Y, et al. Use of the critical-care pain observation tool and the bispectral index for the detection of pain in brain-injured patients undergoing mechanical ventilation: A STROBE-compliant observational study. Medicine (Baltimore). 2018; 97(22): e10985 doi: 10.1097/MD.0000000000010985.

32. Chanques $G$, Tarri T, Ride A, et al. Analgesia nociception index for the assessment of pain in critically ill patients: a diagnostic accuracy study. Br J Anaesth. 2017; 119(4): 812-820 doi: 10.1093/bja/aex210.

33. Charier DJ, Zantour D, Pichot V, et al. Assessing Pain Using the Variation Coefficient of Pupillary Diameter, J Pain. 2017; 18(11): 1346-1353 doi.org/10.1016/j. jpain.2017.06.006.

34. Huei-Jiun C, Yuh-Min Ch. Pain Assessment: Validation of the Physiologic Indicators in the Ventilated Adult Patient, Pain Manag Nurs. 2015; 16(2): 105-111 doi. org/10.1016/j.pmn.2014.05.012.

35. Faritous Z, Barzanji A, Azarfarin R, et al. Comparison of Bispectral Index Monitoring With the Critical-Care Pain Observation Tool in the Pain Assessment of Intubated Adult Patients After Cardiac Surgery. Anesth Pain Med. 2016; 6(4): e38334 doi: 10.5812/aapm.38334. eCollection 2016

36. Günther AC, Bottai M, Schandl AR, et al. Palmar skin conductance variability and the relation to stimulation, pain and the motor activity assessment scale in intensive care unit patients. Crit Care. 2013; 17(2): R51 doi: 10.1186/cc12571.

37. Khanna P, Chandralekha C, Pandey RK, Sharma A. Pain assessment in the critically ill mechanically ventilated adult patients: Comparison between skin conductance algesimeter index and physiologic indicators. Saudi J Anaesth. 2018; 12(2): 204-208 doi: 10.4103/sja.SJA_642_17.

38. Björn A, Pudas-Tähkä S-M, Salanterä S, Axelin A. Video education for critical care nurses to assess pain with a behavioural pain assessment tool: $A$ descriptive comparative study. Intensive Crit Care Nurs. 2017; 42: 68-74 doi.org/10.1016/j. iccn.2017.02.010.

39. Phillips ML, Kuruvilla V, Bailey M. Implementation of the Critical Care Pain Observation Tool increases the frequency of pain assessment for noncommunicative ICU patients. Aust CritCare. 2018;32(5):367-372 doi.org/10.1016/j.aucc.2018.08.007.

40. Asadi-Noghabi AA, Gholizadeh M, Zolfaghari M, et al. Nurses use of Critical Care Pain Observational Tool in patients with low consciousness. Oman Med J. 2015; 30(4): 276-282 doi: 10.5001/omj.2015.55

41. Damico V, Cazzaniga F, Murano L, et al. Impact of a clinical therapeutic intervention on pain assessment, management, and nursing practices in an Intensive Care Unit: A before-and-after study. Pain Manag Nurs. 2018; 19(3): 256-266 doi.org/10.1016/j. pmn.2018.01.007.

42. Georgiou E, Hadjibalassi M, Lambrinou $E$, et al. The impact of pain assessment on critically ill patients' outcomes: A systematic review. Biomed Res Int. 2015; ID 503830 doi: $10.1155 / 2015 / 503830$.

43. Ito $\mathrm{Y}$, Teruya $\mathrm{K}$, Kubota $\mathrm{H}$, et al. Factors affecting pain assessment scores in patients on mechanical ventilation. Intensive Crit Care Nurs. 2017; 42: $75-79$ doi. org/10.1016/j.iccn.2017.03.001.

44. Krupp A, Balas MC. Application of Clinical Practice Guidelines for Pain, Agitation, and Delirium. Crit Care Nurs Clin North Am. 2016; 28(2): 241-252 doi.org/10.1016/j. cnc.2016.02.001.

45. Mansouri P, Javadpour S, Zand F, et al. Implementation of a protocol for integrated management of pain, agitation, and delirium can improve clinical outcomes in the intensive care unit: A randomized clinical trial. J Crit Care. 2013; 28(6): 918-922. doi: org/10.1016/j.jcrc.2013.06.019.

46. Olsen BF, Rustøen T, Sandvik L, et al. Results of implementing a pain management algorithm in intensive care unit patients: The impact on pain assessment, length of stay, and duration of ventilation. J Crit Care. 2016; 36: 207211doi: org/10.1016/j.j.jrc.2016.07.011.

47. Olsen BF, Rustøen $T$, Sandvik $L$, et al. Implementation of a pain management algorithm in intensive care units and evaluation of nurses' level of adherence with the with the algorithm. Heart Lung. 2015;44 (6): 528-533. doi: org/10.1016/ hrtlng.2015.08.001. 
48. Rose L, Haslam L, Dale C, et al. Behavioral pain assessment tool for critically ill adults unable to self-report pain. Am J Crit Care. 2013; 22(3): 246-255 doi: 10.4037/ ajcc2013200.

49. Marra A, Ely EW, Pandharipande PP, et al. ABCDEF bundle in critical care. Crit Care Clin. 2017; 33(2): 225-243 doi: 10.1016/jccc.2016.12.005.

50. Gélinas C. Pain assessment in the critically ill adult: Recent evidence and new trends. Intensive Crit Care Nurs. 2016; 34: 1-11, https://doi.org/10.1016/j.icen.2016.03.001.
Manuscript received/Praca zgłoszona do czasopisma: 02.09.2020

Manuscript accepted/Praca zaakceptowana do druku: 29.12.2020

Translation/Tłumaczenie: Joanna Jensen, Biuro Tłumaczeń OSCAR 